Journal of Southeast Asian

\title{
Letter to My Unborn Self
}

Saymoukda Vongsay

Saymoukda@gmail.com

Follow this and additional works at: https://docs.lib.purdue.edu/jsaaea

Part of the Asian American Studies Commons

\section{Recommended Citation}

Vongsay, Saymoukda (2010) "Letter to My Unborn Self," Journal of Southeast Asian American Education and Advancement. Vol. 5 : Iss. 1, Article 4.

DOI: $10.7771 / 2153-8999.1005$

Available at: https://docs.lib.purdue.edu/jsaaea/vol5/iss1/4

This document has been made available through Purdue e-Pubs, a service of the Purdue University Libraries. Please contact epubs@purdue.edu for additional information.

This is an Open Access journal. This means that it uses a funding model that does not charge readers or their institutions for access. Readers may freely read, download, copy, distribute, print, search, or link to the full texts of articles. This journal is covered under the CC BY-NC-ND license. 


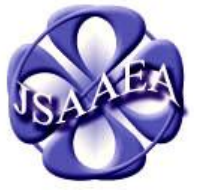

Volume 5 (2010)

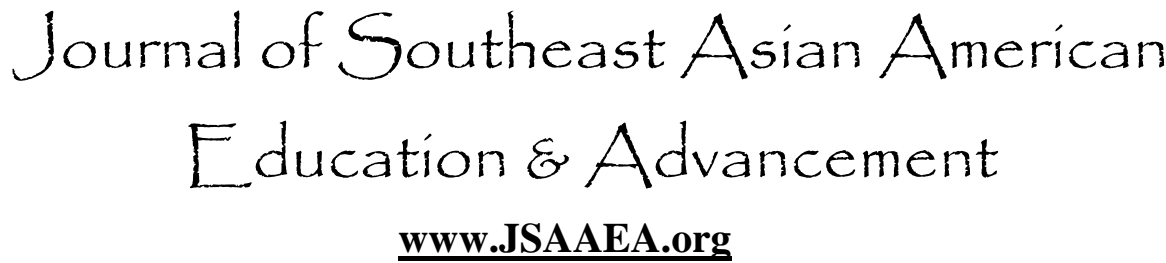

WWW.JSAAEA.org
A peer-reviewed

scholarly journal published by the National Association for the Education \& Advancement of Cambodian, Laotian, and Vietnamese Americans (NAFEA)

\title{
Letter to My Unborn Self
}

\author{
by \\ Saymoukda D. Vongsay
}

Your mother will slap you because out of frustration you'll yell, "Why can't you just learn English?" So what. You're supposed to act as translator at the welfare office. At the grocery stores. At your parent-teacher conferences. This is why they'll raise you bi-lingual in this strange country. On the fourteenth year of your life, you'll be blindsided by the fact that you had a second brother. Don't blame yourself for not knowing. Blame pain and guilt for taking residence in the hearts of your parents the night their second son died in the hospital. Blame their need to forget and their reluctance to heal, to even tell you his name. Be thankful that they didn't give up on having more children after him because then you wouldn't be born.

When you're five years old, your uncle's friend Tom will hurt you, coercing his grown man tongue into your mouth when no one is looking. Tell your uncle so he will beat the shit out of Tom. Don't blame yourself. Don't blame your uncle. Finish the weekend work your third grade teacher sends you home with and go to bed early on Friday nights so that you can wake up two hours before dawn. Don't wear your good clothes. It's only the cucumber fields. Try to daydream about Saturday morning cartoons as you move down the rows, dragging your white bucket behind you. Only pick the ones as big as your hand or your parents won't get paid. Remember to bring a box of facial tissue with you when you go to pick up your mother at the Christmas wreath factory. Don't be disgusted when she cups your face with her dusty sap-dried hands, then kisses you. Fall asleep on the ride home, your head on her lap, and dream of a better life for her.

\section{About the Author}

Vongsay is the Lao American author of No Regrets, a collection of poetry and haikus published by Baby Rabbit Publishing. Her work can be read in publications such as Altra Magazine, The University Register, Hmong Today, and Bakka Literary Journal. A Minnesota-based spoken word poet, she has performed nationally, having shared the stage with nationally acclaimed American artists, and internationally in Italy and Japan. She has worked with the Anchorage Urban League of Young Professionals lecturing and performing at the university level and at local high schools to urge voter registration and civic engagement and also served as liaison between local government and the Southeast Asian community regarding public policy.

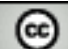

SORERIGHISRESERVEDReaders are free to copy, display, and distribute this article, as long as the work is attributed to the author(s) and the Journal of Southeast Asian American Education \& Advancement, it is distributed for noncommercial purposes only, and no alteration or transformation is made in the work. More details of this Creative Commons license are available at http://creativecommons.org/licenses/by-nc-nd/3.0/. All other uses must be approved by the author(s) or JSAAEA. 


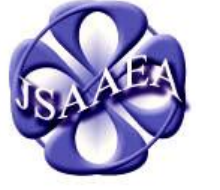

Volume 5 (2010)
Journal of Southeast Asian American

\section{Education \& Advancement}

\author{
wwW.JSAAEA.org
}

Editor

Dr. Wayne E. Wright

University of Texas, San Antonio

Associate Editors

Dr. Chhany Sak-Humphry

University of Hawaii

Dr. KimOanh Nguyen-Lam

California State University, Long Beach

Book Review Editor

Dr. Vichet Chhuon

University of Minnesota

Creative Works Editor

Bryan Thao Worra

Lao Assistance Center

\section{Special Advisor}

Gregory Green

Curator, Echols Collection on Southeast Asia, Cornell University Library

\section{Editorial Assistant}

Kathleen Langham

University of Texas, San Antonio
A peer-reviewed

scholarly journal published by the

National Association

for the Education \&

Advancement of

Cambodian, Laotian,

and Vietnamese

Americans (NAFEA)

Comments and questions for the editorial staff may be directed to jsaaea@ lists.sis.utsa.edu

\section{Editorial Review Board}

\author{
Dr. Carl L. Bankston III \\ Tulane University \\ Dr. Phala Chea \\ Lowell Public Schools \\ Dr. Loan Dao \\ Cancer Prevention Institute of California \\ Dr. Sophal Ear \\ U.S. Naval Postgraduate School \\ Dr. Samlong Inthaly \\ Minneapolis Public Schools \\ Dr. Kevin K. Kumashiro \\ University of Illinois, Chicago
}

\author{
Dr. Pollie Bith-Melander \\ Asian and Pacific Islander Wellness Center \\ Dr. George Chigas \\ University of Massachusetts, Lowell \\ Dr. Changming Duan \\ University of Missouri, Kansas City \\ Dr. Nancy H. Hornberger \\ University of Pennsylvania \\ Dr. Peter Nien-Chu Kiang \\ University of Massachusetts, Boston \\ Dr. Stacey Lee \\ University of Wisconsin, Madison
}


Dr. David Chanpannha Ley Montgomery County Public Schools

Dr. Bic Ngo

University of Minnesota

Dr. Leakhena Nou

California State University, Long Beach

Dr. Mark Pfeifer

Texas A\&M University, Corpus Christi

Dr. Bounlieng Phommasouvanh Minnesota Department of Education

Dr. Kalyani Rai

University of Wisconsin, Milwaukee

Dr. Nancy J. Smith-Hefner

Boston University

Dr. Myluong Tran

San Diego State University

Dr. Linda Trinh Vo

University of California, Irvine

Dr. Zha Blong Xiong

University of Minnesota
Dr. Sue Needham

California State University, Dominguez Hills

Dr. Max Niedzwiecki

Daylight Consulting Group

Dr. Clara Park

California State University, Northridge

Dr. Loan T. Phan

University of New Hampshire

Dr. Karen Quintiliani

California State University, Long Beach

Dr. Fay Shin

California State University, Long Beach

Dr. Yer J. Thao

Portland State University

Dr. Khatharya Um

University of California, Berkeley

Dr. Terrence G. Wiley

Arizona State University

Dr. Kou Yang

California State University, Stanislaus

\section{Doctoral Student Editorial Review Board}

\author{
Keo Chea-Young \\ University of Pennsylvania \\ Peter Tan Keo \\ Columbia University \\ Ha Lam \\ Arizona State University \\ Monirith Ly \\ Texas State University \\ Vanna Som \\ Harvard University \\ Layheng Ting \\ State University of New York, Albany \\ Tinou Tran \\ University of Houston, Texas
}

Annie BichLoan Duong

San Joaquin County Office of Education

Polinda Keo
University at Albany

Ravy Lao

University of California, Santa Barbara

\section{Giang Pham}

University of Minnesota

Rassamichanh Souryasack

University of California, Santa Barbara

Loan Tran

University of California, Riverside

Phitsamay Sychitkokhong Uy

Harvard University

Yang Sao Xiong

University of California, Los Angeles 